\title{
Kalendarium życia kulturalnego Łodzi (cz. 2) 1-15 kwietnia 1945
}

Prezentowany drugi fragment Kalendarium życia kulturalnego Łodzi 1945 roku to element szerzej zakrojonego projektu badawczego, mającego na celu opis kulturowo-ideologicznej rewolucji, przeprowadzonej w latach 1945-1948 przez narzuconą Polsce władzę komunistyczną oraz przez wspierających ją (lub: niesprzeciwiających się jej) pisarzy, ludzi teatru i filmu, dziennikarzy i satyryków, a także przez członków najbardziej aktywnych stowarzyszeń i organizacji młodzieżowych o profilu otwarcie komunistycznym lub kryptokomunistycznym.

Zadanie opisania i scharakteryzowania łódzkiej kultury w pierwszych miesiącach i latach powojennych sytuuje się na przecięciu kilku specjalności humanistycznych: 1) stricte filologicznej, 2) kulturoznawczej, 3) socjologicznej i 4) historyczno-politologicznej. Osoba zamierzająca przedstawić możliwie kompletny obraz tamtej epoki wykroczyć musi poza granice wąsko pojętej analizy i syntezy polonistycznej. Właśnie dlatego prezentowany fragment Kalendarium życia kulturalnego Łodzi 1945 roku, składający się z szeregu zapisów ułożonych wedle porządku chronologicznego, obejmuje również najistotniejsze epizody życia politycznego i społecznego.

W tekście posługuję się skrótami tytułów prasowych:

GL - "Głos Ludu"

PZ - „Polska Zbrojna”

$\mathrm{R}-$ „Robotnik”

RZ - „Rzeczpospolita”

* Zakład Literatury XX i XXI wieku, Instytut Filologii Polskiej, Wydział Filologiczny UŁ, e-mail: pdakowicz@ poczta.onet.pl. 


\section{1-15 kwietnia 1945}

\section{1 kwietnia 1945, niedziela}

1. Uruchomione zostają regularne połączenia lotnicze z Łodzią.

Od 1 kwietnia odbywa się normalna komunikacja lotnicza PLL „Lot” dla pasażerów i poczty. W poniedziałki, środy i piątki kursują samoloty z Warszawy do Łodzi, Krakowa, Rzeszowa, Lublina i Warszawy, zaś we wtorki, czwartki i soboty z Warszawy do Lublina, Rzeszowa, Krakowa, Łodzi i Warszawy (Komunikacja lotnicza, GL 1945, nr 85, s. 4).

\section{3 kwietnia 1945, wtorek}

1. W prasie:

1.1. relacja z symbolicznych „zaślubin” z morzem:

Oddziały kawalerii i delegacja Armii Czerwonej ustawiają się w czworobok. Przystępują do aktu zaślubin. Z pięknie udekorowanej trybuny padają mocne słowa majora Arkuszewskiego i przedstawicieli Armii Czerwonej. Serdeczny pocałunek łączy oficerów armii zaprzyjaźnionych na śmierć i życie. Nie ma końca wiwatom (Ułani witaja morze. Uroczysty akt zaślubin Polski z Battykiem, GL 1945, nr 81 [121], s. 2),

1.2. wiersz Ryszarda Matuszewskiego Idzie wojsko (GL 1945, nr 81 [121], s. 3),

1.3. informacja o zatrudnieniu w Państwowym Konserwatorium Muzycznym w Łodzi wybitnej skrzypaczki Ireny Dubiskiej:

Irena Dubiska objęła klasę skrzypiec w Konserwatorium Państwowym w Łodzi. Znakomita skrzypaczka, jedna z najlepszych interpretatorek dzieł Karola Szymanowskiego, zorganizowała już kwartet smyczkowy i wkrótce wystąpić ma z recitalem skrzypcowym [...] (Irena Dubiska w Łodzi, RZ 1945, nr 87 [227], s. 4),

1.4. satyryczno-propagandowy wiersz Stanisława Sojeckiego pt. Spekulanci (RZ 1945, nr 87 [227], s. 4).

\section{4 kwietnia 1945, środa}

1. Zgromadzenie publiczne dla uczczenia militarnych sukcesów na Pomorzu:

W dniu 4 kwietnia o godzinie 5-ej po południu odbył się w Łodzi wielki wiec manifestacyjny z okazji odzyskania Gdańska i Gdyni. Plac Wolności 
i boczne ulice zapełniły się tłumami ludności. Na trybunie zasiedli przedstawiciele Armii Czerwonej, Wojska Polskiego i partyj politycznych. Do ludności przemówił prezydent miasta - ob. Mijal, wicewojewoda Szuldziński, przedstawiciel Armii Czerwonej, przedstawiciel Wojska Polskiego [...]. Na zakończenie zostały uchwalone depesze powitalne do Marszałka Związku Radzieckiego tow. J. Stalina, do Prezydenta Bieruta, premiera Osóbki-Morawskiego i gen. Roli-Żymierskiego. Orkiestry odegrały narodowe hymny polski i sowiecki (Z okazji odzyskania Gdańska i Gdyni odbyła się w Łodzi wielka manifestacja na Placu Wolności, GL 1945, nr 83 [123], s. 4).

\section{W prasie:}

2.1. artykuł Seweryna Pollaka o krakowskim tygodniku „Odrodzenie”, zawierający między innymi krytykę twórczości Norwida (opartą na tezach drukowanego w "Odrodzeniu" tekstu A. Ważyka ${ }^{1}$ ) oraz uwagi na temat zmian zachodzących $\mathrm{w}$ kulturze; być może po raz pierwszy od instalacji władzy komunistycznej pojawia się tu zarzut „nienadążania” praktyki literackiej za motywowaną ideologicznie teorią:

"Odrodzenie" jest w tej chwili jedynym pismem literackim w Polsce, jedynym pismem poświęconym zagadnieniom kultury, pismem mającym ambicję zagadnienia te stawiać, poddając rewizji przedwojenne, ad usum sanacyjnego reżymu dokonane sformułowania. Niedawno ktoś „krytycznie” nastawiony do obecnej rzeczywistości, starając się pomniejszyć znaczenie „Odrodzenia”, wyraził się: - No cóż, to jest przecież tylko kontynuacja „Sygnałów". Ten sam sklepik z radykalnym towarem literackim. Gdzież im do „Wiadomości Literackich" z ich uniwersalnym podejściem do spraw kultury. Ta krytyka - to bezsilne westchnienie za miękkością kręgosłupa, za galaretowatością kośćca ideowego - jest właściwie największą pochwałą [...] "Odrodzenie" nie jest „,brogiem zboża rozmaitego", ,Odrodzenie” ma swoją linię, jest tym pismem, gdzie krystalizuje się dzisiejsza polska myśl kulturalna w zetknięciu z dzisiejszą rzeczywistością społeczno-polityczną. [...]

[W numerze 16 „Odrodzenia”] Adam Ważyk poddaje rzeczowej, bezkompromisowej krytyce mit Norwida w Polsce dwudziestolecia. Stwierdza, że sanacja spreparowała Norwida dla swoich celów, znajdując w nim zresztą odpowiedni dla swoich celów materiał. Norwidowski postulat pokornej pracy - to przecież najbardziej ożywcze źródełko dla faszystowskich ideologów.

Inne mity poetyckie, mity formalne, tzw. „poezji czystej” obala Jan Kott, biorąc za materiał swych rozważań poezję francuską.

${ }^{1} \mathrm{Z}$ tezami zawartymi w Uwagach o Norwidzie i norwidyzmie Adama Ważyka („,Odrodzenie" 1945, nr 16) polemizował Kazimierz Wyka (Norwid nieobecny „Odrodzenie” 1945, nr 19). Ważyk odpowiedział tekstem Norwid urojony („Odrodzenie” 1945, nr 25). Tę powojenną polemikę na temat aktualności Norwida referuję w książce "Lecz ty spomnisz, wnuku”. Recepcja Norwida w latach 1939-1956. Rzecz o ludziach, ksiażkach i historii, Warszawa 2011, s. 110-121 (podrozdział $W$ zwierciadle ideologii). 
Właśnie ta rewizja dotychczasowych wartości jest zasadniczą cechą „Odrodzenia”. W ten sposób ustalają się podstawy nowego pojmowania rzeczywistości kulturalnej.

Nieco inaczej przedstawia się w „Odrodzeniu” sprawa poezji. W tej dziedzinie praktyka nie nadąża - bo nadążyć nie może - za sformułowaniami teoretycznymi. Widzimy w omawianych numerach wiersze Jerzego Zagórskiego, Miłosza, Ożoga, Leca i in. Przedwojenne rozgraniczenia formalne zachowały się tu w całej pełni (S. Pollak, Trzy numery „Odrodzenia”, GL 1945, nr 82 [122], s. 3),

\section{2. zapowiedź przyjazdu do Łodzi Juliusza Osterwy:}

W dniach najbliższych przybywa do Łodzi znakomity artysta i reżyser polski Juliusz Osterwa, zaproszony specjalnie przez Teatr Wojska Polskiego do reżyserowania dramatu Juliusza Słowackiego Fantazy czyli Nowa Dejanira [sic!]. W sztuce tej ukaże się po raz pierwszy po przerwie sześcioletniej najświetniejsza dziś aktorka młodszego pokolenia Janina Romanówna (Juliusz Osterwa w Łodzi, PZ 1945, nr 60, s. 4),

2.3. w dziale Żotnierze pisza „Polski Zbrojnej” wiersz Wacława Mrozowskiego Powrót nad morze (PZ 1945, nr 60, s. 3),

2.4. felieton Stanisława Ryszarda Dobrowolskiego wzywający pisarzy do aktywnego włączenia się przemiany społeczne:

Byłem niedawno przez kilkanaście godzin w Żyrardowie. Przy okazji skorzystałem z zaproszenia i uczestniczyłem $\mathrm{w}$ otwarciu świetlic robotniczych na terenie tamtejszych zakładów pracy [...]. Żyrardów [...] to [...] bodaj najpoważniejszy ośrodek robotniczy okręgu warszawskiego - z tradycjami i to jakimi! Ludzie się tam palą do roboty kulturalnej. [...] Ale trzeba im w tem pomóc. Brak im wiele [sic!] rzeczy. Nie ma komu doradzić, nie ma komu wskazać, gdzie tych tekstów szukać... Podobnie jak w Żyrardowie jest i w wielu, wielu ośrodkach robotniczych w kraju. Nie mówię już o wsi. [...]

Są robotnicze domy kultury, są świetlice po zakładach pracy, organizuje się zespoły artystyczne, teatralne - wszystko to musi być wypełnione żywą treścią. Tylko najbardziej zainteresowani - nie wszyscy w dostatecznym stopniu się interesują, pracują - i owszem, ale tylko w Łodzi. A to jest za mało (S.R. Dobrowolski, Uspołecznić prace pisarska!, R 1945, nr 80 [110], s. 3),

2.8. propagandowa prezentacja zakresu działań koncesjonowanej Polskiej Partii Socjalistycznej na terenie Łodzi i województwa łódzkiego²:

${ }^{2}$ Do daleko posuniętego sceptycyzmu wobec doniesień o „bardzo żywej aktywności młodzieży" działającej w strukturach koncesjonowanej PPS skłania lektura wspomnień Zygmunta Zaremby, wybitnego działacza konspiracyjnej Polskiej Partii Socjalistycznej (do wiosny 1944 r. PPS-WRN). W opublikowanych na emigracji wspomnieniach pisał Zaremba: „Towarzysze, którzy zachodzili do komitetu koncesjonowanej PPS [w Krakowie] i wysłuchiwali 
Po wyjściu z podziemi Polska Partia Socjalistyczna wznowiła działalność $\mathrm{w}$ imię tradycyjnych haseł walki o socjalizm i niepodległość. [...]

$\mathrm{Ci}$, którzy ocaleli, zabrali się energicznie do pracy. Zorganizowano we wszystkich punktach miasta Dzielnice. Jest ich 12. Każda z Dzielnic posiada Świetlice, urządza wiece [...]. Dyskusja wywiązująca się po prelekcjach świadczy o zainteresowaniu słuchaczy. Każda Dzielnica tworzy Koła Fabryczne, Domowe i Kobiet, stara się dać członkom maximum opieki. Organizowane są przy każdej Dzielnicy zespoły sportowe i gimnastyczne, zebrania towarzyskie, dyskusyjne i inne, o charakterze oświatowym. [...]

Mająca się wkrótce otworzyć na naszym terenie szkoła dla prelegentów skupi, prócz kandydatów dzielnicowych, również słuchaczy z prowincji. [...]

Równolegle rozwija swą działalność Organizacja Młodzieży TUR. Tworzone są Świetlice, Koła Sportowe i Gimnastyczne. Scenki amatorskie, orkiestra i chór mają wielu zwolenników. Aktywność młodzieży jest bardzo żywa. Wiele dotąd niewykorzystanych talentów wyzwoli się i przysporzy społeczeństwu wartościowych ludzi. [...]

Aby uratować bibliotekę partyjną, w krytycznej chwili porozdawano książki między towarzyszy. Wiele z nich, na skutek działań wojennych, zaginęło, wiele jednak udało się uratować i przechować. Te wracają na półki biblioteczne. Ponadto przybywa dużo książek w formie darów dla Biblioteki Polskiej Partii Socjalistycznej. [...]

Biuletyn Polskiej Partii Socjalistycznej nadawany będzie przez radio w każdy wtorek i piątek o godz. 11.30 do 11.40 (Eódzka organizacja PPS przy pracy, R 1945, nr 80 [110], s. 4).

\section{5 kwietnia 1945, czwartek}

1. W „Robotniku” fragment rozporządzenia ministra oświaty dotyczący wspierania politycznej i społecznej aktywności młodzieży:

Celem ułatwienia starszej młodzieży szkolnej wzięcia czynnego udziału w życiu kraju należy umożliwić młodzieży klas licealnych oraz młodzieży

peror [Bolesława] Drobnera, wygłaszanych często przy prawie pustej sali, opowiadali mi o tym jak o przedstawieniu, o demonstracji fikcji, która nie ma nic wspólnego z rzeczywistością. Niestety, była to najbardziej rzeczywista rzeczywistość. Nowa władza obejmowała wszystkie nici administracji i policji, nie tylko kneblując usta przeciwnikom i dyrygując zmonopolizowaną prasą, lecz także coraz głębiej przenikając przy pomocy sfory szpiclów w życie obywateli. [...] Za bufonadą Drobnerów szło konsekwentne przędzenie pajęczej sieci systemu dyktatury" (Z. Zaremba, Wojna i konspiracja, Kraków 1991, s. 415). Przyznawał jednak, że czas działał na korzyść „namiastek” i „falsyfikatów” przedwojennych ugrupowań politycznych: „musiały [partie koncesjonowane] przyciągać ludzi dezorientowanych coraz bardziej zalewem urzędowej propagandy. Odpór, jaki dawały jej nasze ustne wyjaśnienia, nie mógł być skuteczny poza kręgiem bardziej wyrobionych i powiązanych ze sobą towarzyszy. Ale nawet i oni musieli w końcu ulegać ujawniającemu się masowemu pędowi do organizacji, poddawać się nastrojom szukania rozwiązań przez wejście, opanowanie od wewnątrz i nadanie prawdziwej treści lubelskim namiastkom organizacyjnym" (tamże, s. 417). Można się domyślać, że procesy te były jeszcze lepiej widoczne w młodzieżowych „przybudówkach” partii. 
starszych klas gimnazjów, która ukończyła lat 16, należenie do młodzieżowych organizacji ideowo-wychowawczych, takich jak: Organizacja Młodzieży TUR [przed wojną związana z PPS, obecnie z jej koncesjonowanym odpowiednikiem], Związek Walki Młodych [organizacja komunistyczna, utworzona w 1943 r.], Związek Młodzieży Wiejskiej „Wici” [przed wojną związany ze Stronnictwem Ludowym, po wojnie z jego koncesjonowanym odpowiednikiem], Sekcja Młodych Stronnictwa Demokratycznego [związana z koncesjonowanym SD]. Praca młodzieży w tych organizacjach stanie się jednym ze skutecznych sposobów jej wychowania społecznego, ułatwi jej zdobycie światopoglądu, przysposobi młodzież do pełnienia zadań obywatela demokratycznego państwa (Udziat młodzieży szkolnej w pracach organizacji społeczno-oświatowych, R 1945, nr 81 [11], s. 4)³.

\section{6 lub 7 kwietnia $1945^{4}$}

1. Edmund Jan Osmańczyk przyjeżdża do Łodzi na zaproszenie Jerzego Borejszy. Z Łodzi zostaje przewieziony do Warszawy, gdzie spotyka się z prezesem SW "Czytelnik":

Po krótkim pobycie w Krakowie ruszyłem do Łodzi, dokąd wzywał mnie major Jerzy Borejsza montujący ekipę korespondentów wojennych „Czytelnika”. Dowiedziawszy się o mym zgłoszeniu na ochotnika do I Armii, zdecydował za mnie, że będę korespondentem prasy czytelnikowskiej.

W Łodzi nie dano mi odsapnąć, załadowano na kukuruźnika i po godzinie byłem [...] na najtragiczniejszym pobojowisku II wojny światowej (E.J. Osmańczyk, Byt rok 1945..., Warszawa 1970, s. 124).

\section{7 kwietnia 1945, sobota}

1. Prezydent Łodzi Kazimierz Mijal (PPR) zostaje wybrany na stanowisko prezesa Łódzkiego Klubu Sportowego (Nowe władze ŁKS-u, GL 1945, nr 86 [126], s. 8).

2. Pierwszy z cyklu koncertów jazzowych w kinie „Bałtyk”:

Zespół muzyki jazzowej „Wesoła 16-tka” da kilka koncertów w lokalu kina „Bałtyk”, Narutowicza 20. Inauguracja [sic!] koncertu w sobotę 7.4. o godz. 17-ej (Gościnne występy „Wesołej 16-tki”, RZ 1945, nr 91 [131], s. 4).

${ }^{3}$ W lipcu 1948 roku z wszystkich wymienionych organizacji zostanie utworzony jednolity komunistyczny Związek Młodzieży Polskiej.

${ }^{4}$ E.J. Osmańczyk błędnie określa datę uruchomienia pierwszej drukarskiej maszyny rotacyjnej w powojennej Warszawie (7 kwietnia 1945). Fakt, że wydarzenie to miało miejsce w niedzielę 8 kwietnia (zob. J. Zagościński [J. Huszcza], Pierwsza rotacja warszawska, RZ 1945, nr 94 [234], s. 4), pozwala przesunąć terminus ad quem przybycia Osmańczyka do Łodzi na 7 kwietnia. 
3. $\mathrm{W}$ prasie:

3.1. w "Głosie Ludu”, organie PPR, ogłoszenie o nabożeństwie w intencji zmarłych artystów:

W nadchodzący piątek o godzinie 8 rano w kościele ojców Jezuitów pod wezwaniem Św. Jana (ul. Sienkiewicza 60) - odbędzie się msza święta za dusze zmarłych lub zamordowanych w czasie okupacji niemieckiej artystów warszawskich: Stanisławy Wysockiej, Aliny Halskiej, Marii Przybyłko-Potockiej, Heleny Sulimy, Stanisława Stanisławskiego i Mariusza Maszyńskiego (Nabożeństwo za artystów, GL 1945, nr 84 [124], s. 4),

3.2. w „Robotniku” felieton Jerzego Waldorffa na temat łódzkiej kultury w pierwszych tygodniach po zakończeniu okupacji niemieckiej:

Życie kulturalne wielkiego miasta! Jak apetyczny byłby to kąsek dla felietonisty i z jakże by miłym łączył się bytem: tu premiera, tam koncert, ówdzie odczyt, a jeszcze gdzie indziej konferencja prasowa, wszystko zaś przeplatane szeregiem herbatek, rautów czy półprywatnych zebrań u znakomitości artystycznych lub dygnitarzy... - Byłby, gdyby wojna była już skończona i życie toczyło się normalnym torem. Tymczasem toczy się jeszcze wojna i życie kulturalne Łodzi, choć zapoczątkowane z tak doskonałym rozmachem i rokujące świetne nadzieje, przedstawia bardzo skomplikowany obraz i składa się nie tylko z samych stron przyjemnych. Tym niemniej jest ogromnie ciekawe, może ciekawsze od tego, jakie będzie, skoro wojna się skończy i wszystko powróci do tradycyjnego łańcucha premier, koncertów, wystaw i herbatek (J. Waldorff, Kto późno do Łodzi..., R 1945, nr 83 [113], s. 4).

\section{8 kwietnia 1945, niedziela}

1. Uroczyste otwarcie Centralnej Szkoły Partyjnej PPR. Adres: al. Kościuszki 65. Wśród gości: Władysław Gomułka, Zenon Kliszko, Jakub Berman, Hilary Minc, Ignacy Loga-Sowiński, przedstawiciel Armii Czerwonej generał major Porfiryj Furt. Uczestnicy uroczystości wysłuchali referatu towarzysza „Wiesława” oraz obejrzeli program artystyczny (wykonawcy: „ob. ob. Chojnacka, Mira Zimińska, Bereżyński, Irena Dubiska, Arno i Charitonowa"). Na koniec odśpiewano Międzynarodówkę i Rotę:

Dziś wspaniały „szklany dom” staje się ogniskiem oświaty robotniczej, będzie z niego promieniować na cały kraj światło czystej niewypaczonej teorii, która zrealizowana w praktyce, przebuduje nasz naród od podstaw i powiedzie ku nowej świetlanej przyszłości (Otwarcie Centralnej Szkoty Partyjnej PPR, GL 1945, nr 88 [128], s. 3). 
2. W Teatrze Wojska Polskiego ponowna prezentacja programu artystycznego Od Oki do Wisty, który "spotkał się z entuzjastycznym przyjęciem publiczności łódzkiej" (Od Oki do Wisty, PZ 1945, nr 60, s. 4).

\section{Recital skrzypcowy Ireny Dubiskiej:}

W niedzielę, dnia 8 bież. mies. punktualnie o godz. 4 pp. w sali Państwowego Konserwatorium Al. 1-go Maja 6 odbędzie się recital skrzypcowy p. Ireny Dubiskiej. W programie m.in. Sonata Kreutzerowska. Przy fortepianie p. Maria Wiłkomirska (Recital skrzypcowy, RZ 1945, nr 90 [230], s. 4).

4. Uroczyste otwarcie świetlicy przy dawnej fabryce Geyera, ul. Piotrkowska 295 (Otwarcie świetlicy w zakładach Geyera, RZ 1945, nr 92 [232], s. 6).

5. Uroczyste otwarcie Szkoły Oficerskiej WP w Łodzi, poprzedzone mszą świętą polową (Otwarcie Szkoty Oficerskiej w Łodzi, RZ 1945, nr 93 [233], s. 4).

6. W Robotniczym Domu Kultury (ul. Piotrkowska 243) akademia z okazji wznowienia działalności hufców Przysposobienia Wojskowego. Wcześniej msza święta polowa i defilada. Obecni przedstawiciele władz cywilnych i wojskowych (Wznowienie prac Przysp. Wojskowego, R 1945, nr 82 [112], s. 4).

7. Organizowana przez koncesjonowaną PPS akademia z okazji zdobycia Gdańska oraz spektakl Wóz Drzymaty:

Polska Partia Socjalistyczna urządza w niedzielę, dnia 8-go kwietnia rb., o godz. 11-ej rano, w sali śpiewaków przy ul. 11-go Listopada 21 UROCZYSTĄ AKADEMIĘ ku uczczeniu wiekopomnego faktu odzyskania GDAŃSKA. Na program Akademii złożą się: przemówienia i część artystyczna. Po Akademii wystawiona zostanie sztuka pt. Wóz Drzymały, napisana przez ob. Ręczkowskiego Józefa, reżyserowana przez ob. Pilarskiego Józefa, w której udział wezmą artyści scen łódzkich. Bilety w cenie zł. 5 do nabycia w Dzielnicach PPS i w kasie (R 1945, nr 83 [113], s. 4).

Sala wypełniona była po brzegi, ze wszystkich dzielnic przybyły liczne delegacje towarzyszy, na twarzach obecnych malowała się radość, robotnicza Łódź przybyła tłumnie manifestować przywiązanie do ziem zachodnich, do ważności odzyskania polskiego morza. Nastrój wśród przybyłych uroczysty, starzy, wypróbowani w walkach towarzysze z dumą spoglądali na czerwone, socjalistyczne sztandary, którymi pięknie przystrojona była scena sali. [...]

Referat o znaczeniu i roli polskiego morza i odzyskanych portów wygłosił Pełnomocnik Tymcz. Rządu Rzeczypospolitej przew. WKR PPS tow. [Jan] Haneman. [...] [M]ówca wzniósł powtórzony z entuzjazmem przez zgromadzonych okrzyk na cześć Wolnej, Niepodległej i Demokratycznej Polski.

Następnie płomienne przemówienie, przerywane gromkimi oklaskami i okrzykami na cześć wolności, niepodległości i socjalizmu, wygłosił red. tow. [Artur] Karaczewski. 
W części artystycznej zapoczątkowanej recytacją zaktualizowanej Pieśni o Bałtyku nastąpiła bardzo pięknie wykonana część wokalno-artystyczna, na którą złożyły się utwory Chopina i Moniuszki w wykonaniu ob. Haliny Gastman (fortepian) i ob. Haliny Zachert (śpiew). Poza tym odegrano sztukę Raczkiewicza reżyserowaną przez ob. Józefa Pilarskiego Wóz Drzymały.

Popłynęły słowa Roty. Robotnik łódzki swoją postawą i świadomością klasową raz jeszcze zadokumentował wysokie poczucie patriotyzmu i głęboką troskę o losy swego Państwa i narodu.

Przy dźwiękach Czerwonego Sztandaru opuszczali zebrani podniosłą uroczystość, która zarówno swoim przebiegiem, organizacją i powagą świadczyła dobitnie o żywotności i sprawności łódzkiej organizacji partyjnej (PPS uczciła przyłaczenie Gdańska, R 1945, nr 86 [116], s. 4).

8. Zebranie wyborcze członków Związku Zawodowego Artystów Cyrkowych w lokalu Referatu Cyrkowego, ul. Cegielniana 32 (Zebranie Artystów Cyrkowych, R 1945, nr 80 [110], s. 4).

9. Warszawa. Część łódzkiego środowiska literackiego i prasowego uczestniczy w zorganizowanej przez SW „Czytelnik” uroczystości uruchomienia drukarskiej maszyny rotacyjnej:

Na razie jeździ się do Warszawy przeważnie autobusami, wraca się do Łodzi, aby odzyskać lepsze samopoczucie. Komunikacja kolejowa z inną częścią kraju urywa się na Pradze. Po moście przez Wisłę idzie się pieszo lub jadąc na łebka podryguje się w przygodnych ciężarówkach. Pracując w Łodzi, uczestniczymy $\mathrm{w}$ rozmaitych uroczystościach warszawskich, stale coś inaugurujących. W niedzielę 8 kwietnia 1945 roku zgromadziliśmy się w Domu Prasy przy ulicy Marszałkowskiej, aby zapamiętać moment puszczenia $w$ ruch maszyny rotacyjnej. Ludnie było i gwarnie - zebrało się może ze czterysta osób: literaci i dziennikarze, działacze i inżynierowie, towarzysze sztuki drukarskiej. Podano nawet trochę wódki. Jerzy Borejsza - szczególnie tego dnia zadowolony, tak że na poczekaniu można byłoby namówić go na akceptację przynajmniej dwóch nowych pism - powołał się na zwyczaje panujące pono w Hiszpanii i zaproponował zbiorowe wypicie bruderszaftu przez wszystkich znajomych i nieznajomych (J. Huszcza, Zdarzenia i zwierzenia, Łódź 1965, s. 124-125).

10. W prasie:

10.1. w „Robotniku” felieton Leona Gomolickiego i Stanisława Ryszarda Dobrowolskiego na temat związków między kulturą niemiecką a zbrodniami okresu okupacji (Krew na butach, R 1945, nr 84 [114], s. 4),

10.2. w „Rzeczpospolitej” ogromny blok tekstów poświęconych sukcesom militarnym na Pomorzu oraz znaczeniu nadbałtyckich miast dla przyszłości państwa polskiego; między innymi:

10.2.1. fragmenty dzieł Szymona Askenazego, Juliana Tuwima, Adama Mickiewicza, Galla Anonima, Jana Długosza, 
10.2.2. felieton Jerzego Wyszomirskiego Jedna zima w Gdyni, z jednoznacznym przeciwstawieniem porządku przedwojennego (Polska sanacyjna) porządkowi powojennemu (Polska „demokratyczna"):

Wiatry i mróz nastrajają mnie pesymistycznie. Toteż zimą spojrzałem na Gdynię inaczej niż w karnawale letnim. Widziałem dużo plam na jej pięknym malowidle. Ale na plamy te składała się nie natura, lecz ludzie. Nie spodobali mi się gdynianie w codziennym, mroźnym życiu. Wziąłem z czytelni (a czytelni było zawstydzająco mało i przykro ubogich) Ziemie obiecana Reymonta i dostrzegłem niezaprzeczone podobieństwo pomiędzy ówczesnym gdynianinem a tym okazem „Lodzermenscha”, jaki żerował po Łodzi pół wieku temu. Oczywista, we wszystkich klondajkach świata musi się zjawiać typ wyzyskiwacza, oszusta, nabieracza, awanturnika, amatora lekkiego zarobku, niebieskiego ptaka, a także brutala, który bez skrupułów dąży do zrobienia majątku w najszybszym czasie. [...] Kant, lipa, machlojka - słówka obiegowe u nas przed wojną - wcielały się w Gdyni w czyn na każdym kroku, znajdowały najdoskonalsze pokrycie rzeczowe, które świadczyło o tym, że życie gospodarcze i społeczne w tym mieście toczy skir zgnilizny. [...]

Od mojej zimy, spędzonej na polskim wybrzeżu, mija prawie dziesięć lat. [...] Wracamy dziś nad polskie morze. Natura się tam nie zmieniła. [...] Ale ludzie zmienią się niewątpliwie. Zniknie haniebny typ wyzyskiwacza i dorobkiewicza. Zniknie bezmyślny biurokrata-karierowicz, przemawiający błazeńsko-urzędowym stylem [...], wyrosną białe domy z czerwonymi dachami, otoczone wieńcem ogrodów. Nie będzie tam dogorywających gruźlików i mrących z głodu niemowląt w łachmanach. Ludzie będą mieli jasne spojrzenie i uśmiech na twarzy, zdrowie i siłę w ciele, a w sercu miłość (J. Wyszomirski, Jedna zima w Gdyni, RZ 1945, nr 92 [232], s. 4-5),

10.2.3. wiersz Leopolda Lewina Nowe Termopile, datowany „1940" (RZ 1945, nr 92 [232], s. 4).

\section{8-15 kwietnia 1945}

1. Kurs „ideowo-programowy” zorganizowany przez Związek Młodzieży Wiejskiej „Wici”:

Program kursu obejmuje referaty o ruchu ludowym i młodzieżowym, przemianach społecznych, roli chłopów w życiu państwa, reformie rolnej, kulturze wsi i innych. Aby nawiązać ścisły kontakt z młodzieżą miasta Łodzi uczestnicy kursu biorą udział w urządzanych dla nich przez Związek Walki Młodych i T.U.R. wieczorkach (Kurs „Wici”, R 1945, nr 87 [117], s. 4). 


\section{9 kwietnia 1945, poniedziałek}

1. W prasie:

1.1. informacja o rychłym ukazaniu się pierwszego numeru „Kuźnicy”, określanej jako „dwutygodnik społeczno-literacki”, pod redakcją Zofii Nałkowskiej (Kronika kulturalna, GL 1945, nr 86 [126], s. 3),

1.2. nota na temat powieści Wandy Wasilewskiej Tęcza:

Powieść Wandy Wasilewskiej Tęcza, która ukazała się w druku w 1942 r., a której tematem jest życie wsi ukraińskiej pod okupacją niemiecką, została przetłumaczona na szereg języków europejskich, m.in. na rosyjski, angielski, francuski, szwedzki itd. Wasilewska za powieść tę otrzymała nagrodę Stalina. Opracowany na podstawie tej powieści film należy do najlepszych w wojennej kinematografii radzieckiej. Obecnie w „Nowych Widnokręgach" drukuje się nowa powieść Wasilewskiej Po prostu mitość (Kronika kulturalna, GL 1945, nr 86 [126], s. 3),

1.3. artykuł Mieczysława Jastruna stanowiący podsumowanie lat wojennych i pierwszych miesięcy roku 1945:

Dwa miesiące z górą upłynęły od chwili, [...] gdy patrzyłem na zwęglone trupy spalonych męczenników więzienia na Radogoszczu. Pierwsze pąki pierwszej wolnej wiosny wytryskują z ogrodów Łodzi, pierwsze trawy, poprzerastane jeszcze uschniętą zielenią, która pamięta niewolę, mówią znów o wiecznym powrocie życia i młodości (M. Jastrun, Na drogach wojny, GL 1945, nr 86 [126], s. 4),

1.4. blok tekstów poświęconych szkolnictwu wyższemu, między innymi artykuły Romana Werfla i profesora Henryka Raabe, rektora UMCS:

Sześć wyższych uczelni działa w Krakowie. Rozpoczyna już działalność Uniwersytet warszawski [sic!]. Szereg innych szkół akademickich warszawskich organizuje już normalny tok nauczania - na razie $\mathrm{w}$ innych ośrodkach kraju. Pracują normalnie dwie uczelnie w Lublinie. Łódź, przed wojną kopciuszek Polski, jeśli idzie o sprawy szkół wyższych, stała się miastem uniwersyteckim i posiadać będzie prawdopodobnie kilka wyższych uczelni. Jeszcze wśród huku dział - w chwili, gdy przeważna część wysiłków narodu skierowana jest, skierowana być musi, na kontynuowanie walki, na ostateczne rozgromienie hitleryzmu - odrodzone Państwo Polskie zdobyło się na wysiłek uruchomienia wyższych uczelni w skali szerszej nawet niż przed wojną.

Ale właśnie to skłania nas do tym baczniejszej uwagi w stosunku do tego, co się dzieje na uniwersytetach.

Obóz demokracji polskiej szanuje autonomię uniwersytecką. Ale celem tej autonomii jest zabezpieczenie swobodnego rozwoju nauki, a nie 
zabezpieczenie swobodnej działalności dla reakcyjnych klik lub bezkarności dla zdrajców narodu (R. Werfel, Uczelnie wyższe - sprawa Narodu, GL 1945, nr 86 [126], s. 7).

Stosunek do państwa i społeczeństwa szkoły wyższej z okresu wielkich przemian demokratycznych musi być zupełnie inny, niż był w okresie sanacyjnym. [...] [O]becna szkoła wyższa musi współpracować z państwem nad wyszkoleniem obywateli o pełnej świadomości demokratycznej, umiejących w każdych warunkach pracować ze zrozumieniem nad odbudową państwa i nad tworzeniem jego potęgi (H. Raabe, Nieco o szkolnictwie wyższymi, GL 1945, nr 86 [126], s. 7),

1.5. artykuł podsumowujący pierwsze dwa tygodnie działalności Uniwersytetu Łódzkiego:

Utworzony Uniwersytet Państwowy w Łodzi [...] dziś obejmuje następujące wydziały: matematyczno-przyrodniczy, humanistyczny, nauk społecznych i pedagogiczny z działem pracy kulturalnej - ogółem pracują 92 katedry. Większość katedr jest w tej chwili obsadzona. [...] [P]rzy obsadzaniu katedr sięgnięto do licznego grona uczonych polskich, ludzi często o poważnym dorobku naukowym, którzy w Polsce przedwrześniowej z tych czy innych względów nie mogli się habilitować. Otwarcie katedr akademickich dla tych kadr pracowników naukowych z jednej strony wypełni luki spowodowane przez wojnę, a z drugiej - otworzy drogę do habilitacji tym, którzy w swej pracy pedagogicznej wykażą swą wiedzę i zdolności. [...]

Napływ słuchaczy duży. [...] Ogólna ilość słuchaczy wynosi 700 osób. Trwają jeszcze zapisy na wydziały humanistyczny i pedagogiczny i sekcję prawno-sądową wydziału nauk społecznych. [...]

Warunki pracy ciężkie. Pomieszczenie, z którego korzysta Uniwersytet, jest zbyt ciasne na potrzeby wyższej uczelni. [...]

Poważną bolączką uniwersytetu [...] jest brak bursy dla słuchaczy.

Źle przedstawiają się również stosunki mieszkaniowe i zaopatrzeniowe profesorów. [...]

Uniwersytet Państwowy w Łodzi - mieście robotniczym - ma specjalnie wielkie znaczenie i dlatego też należałoby otoczyć go specjalną opieką (E.D., Uniwersytet Państwowy w Łodzi, GL 1945, nr 86 [126], s. 8),

1.6. zachęta do czytania świeżo wydanych tomików „Biblioteczki Peperowca” (W. Gomułka, PPR w walce o niepodległość Polski; Z. Kliszko, Walka PPR o Front Narodowy w okresie okupacji; zbiory artykułów: Wspomnienia z pracy i walki; O Zwiazku radzieckim; O Leninie i Stalinie; Reforma Rolna; O partii; O polityce zagranicznej):

Robotnik Łodzi, Dąbrowy, Świętochłowic, od dawna związany z naszym ruchem, staje, niemal automatycznie, pod naszym sztandarem, wiedząc, 
że jest to sztandar marksizmu-leninizmu, jego sztandar, ale ten robotnik nie zawsze wie, jak należy konkretnie w warunkach dzisiejszej polskiej rzeczywistości zastosować naszą marksistowską metodę myślenia, nie zawsze rozumie $\mathrm{w}$ pełni, dlaczego partia nasza prowadzi taką właśnie, a nie inną politykę. Temu zaradzić ma „Biblioteczka Peperowca” [...] (Biblioteczka peperowca, GL 1945, nr 87 [127], s. 3),

1.7. rozmowa z Aleksandrem Zelwerowiczem na temat teatru w „dzisiejszej Polsce":

- Po jakiej linii i w jakiej formie ma nastąpić upowszechnienie teatru?

Z tym pytaniem zwróciliśmy się do znakomitego artysty i reżysera Aleksandra Zelwerowicza, występującego obecnie po blisko 6 latach okupacji w Weselu w Teatrze Wojska Polskiego w Łodzi.

- Upowszechnienie teatru - odpowiada Zelwerowicz - rozpocząć należy od przygotowania publiczności i aktora. Pierwszym niejako etapem byłoby stworzenie ideowego teatru dla dzieci. Znakomite placówki tego rodzaju istnieją w Rosji, np. teatr „Młodego Widza” pod kierunkiem Natalii Satz. [...] Oddzielnym typem jest moim zdaniem teatr dla młodzieży do lat 14 i dorastającej, na którego repertuar składać się powinny tematy z historii literatury: Dziady, Kordian, klasyczne komedie Fredry, Zabłockiego itp., wystawiane $\mathrm{w}$ porozumieniu z polonistami. [...]

Ważnym problemem jest także organizacja teatru ludowego [tj. teatru przygotowującego spektakle „dla rzesz pracujących"]. [...]

Na razie należy poprzestać na wielkim repertuarze, oczekując na nowych pisarzy, na utwory dosłownie związane z chwilą. [...] Od dramaturgów żądać należy utworów aktualnych, lecz o wysokim poziomie artystycznym. Jeśli chodzi o publiczność, to jej teatralne kształcenie opierać się winno na wielkiej literaturze, komedii klasycznej i czystej komedii fredrowskiej, jak np. Pan Jowialski, która ma wiele elementów społecznych. Do typu komedii społecznych bardzo dziś aktualnych należą m.in. Rozbitki Blizińskiego, przedstawiające rozkład i schyłek środowisk mieszczańskich i ziemiańskich, w przeciwstawieniu do typu Strasza, człowieka z ludu, wybijającego się siłą woli i moralną tężyzną. [...] [N]auczanie publiczności zacząć należy od trzech wieszczów - poprzez Norwida do Wyspiańskiego, a przez ten czas mogą narodzić się rzeczy nowe, pełnowartościowe.

W popularyzacji teatru odegrają olbrzymią rolę związki zawodowe i organizacje społeczne, urządzając konferencje i pogadanki, przygotowując widza do widowisk oraz inscenizując fragmenty wystawianych sztuk we własnych kółkach amatorskich. [...] Osobiście - mówi Zelwerowicz - poddałem dwa tematy i chcę je referować w Łodzi, mianowicie: O czystości i pięknie naszej mowy oraz Skąd powstat i czym jest teatr.

Organizując teatr dla mas, musimy sięgnąć po wzory do teatru radzieckiego. Powszechnie wiadomo, że w całej Europie wszelkie śmielsze poczynania na wielkich scenach były i są wzorowane na teatrze 
radzieckim. To, co jest podstawą teatru Stanisławskiego, nie tylko można, ale należy brać za podstawę przy budowie fundamentów nowego teatru. [...] Toteż możność znlezienia się w Moskwie przyniosłaby pracownikom polskiego teatru olbrzymie korzyści. [...]

Wreszcie ostatnim, niesłychanie ważnym zagadnieniem jest demokratyzacja teatru. Zdaniem Zelwerowicza każda większa grupa zawodowa powinna mieć własny teatr, tak jak już ma obecnie stołówki, bloki mieszkalne, świetlice (J. Sokolicz-Wroczyński, Teatr dla wszystkich w dzisiejszej Polsce. [Rozmowa z Aleksandrem Zelwerowiczem], RZ 1945, nr 94 [234], s. 3).

\section{0 kwietnia 1945, wtorek}

1. Konferencja sekretarzy PPR z terenu województwa łódzkiego (Konferencja woj. sekretarzy Komitetów powiatowych i miejskich PPR w Łodzi, GL 1945, nr 90 [130], s. 3).

2. W „Robotniku” (1945, nr 86 [116]):

2.1. wiersz Jana Piotrowskiego Umarłe recce (s. 3),

2.2. felieton Leona Gomolickiego Westerplatte broni się... (s. 3),

2.3. gwałtowna krytyka twórczości poetyckiej Juliana Przybosia oraz polemika z tezami jego artykułu Z teorii dzieła literackiego („Odrodzenie" 1945, nr 19), podpisana inicjałami „G.I.":

Powiem od razu: nie zrozumiałem ani jednego wiersza [spośród utworów Przybosia wydrukowanych w 17 numerze „Odrodzenia”], ani jednego zdania, poczynając od tytułu pierwszego wiersza (Ziemia gwiezdnie pojęta) do ostatniego zdania wiersza („Bezczynny jak się chwycił pierwszej z kraju jabłoni, jak, patrząc, jął się skowronka").

Przyznaję się do tego tym chętniej, że zrobiłem małą ankietę wśród znajomych (inteligentów, robotników itd.), którzy mi oświadczyli albo, że „Przybosia nie czytają, bo i tak nic nie można zrozumieć”, albo że próbowali czytać te wiersze i wynik był ten sam - nie zrozumieli.

Postanowiłem więc wziąć na siebie rolę dziecka z bajki Andersena, które na głos krzyknęło: „Przecież król jest nagi”.

$\mathrm{Na}$ zakończenie zacytuję jeszcze dwa zdania z artykułu teoretycznego ob. Przybosia. Pierwsze brzmi: „Wojna ujawniła słabość wielu poezyj wielu poetów". Z tym całkowicie się zgadzam. Drugie zdanie, którym ob. Przyboś zaczyna swe wywody, brzmi: „Trudniej niż poezje pisać o poezji”. $\mathrm{Z}$ tym absolutnie nie zgadzam się. O wiele łatwiej jest pisać o poezji niż poezje. Wydaje mi się, że praktyka ob. Przybosia zadaje kłam tej teorii.

Nie mam za złe ob. Przybosiowi, że pisze tego rodzaju wiersze. To jego prywatna sprawa. Dziwię się tylko redaktorowi "Odrodzenia”, że je drukuje. Czyżby był wyznawcą zasady: „Sztuka dla sztuki”? (G.I., Teoria i praktyka ob. Przybosia, R 1945, nr 86 [116], s. 3). 


\section{po 10 kwietnia 1945}

1. Kilkudniowy pobyt Edmunda Jana Osmańczyka w Łodzi:

10 kwietnia 1945 roku byłem z majorem Jerzym Borejszą we Włochach pod Warszawą, gdzie po zameldowaniu się u generała brygady Mariana Spychalskiego, ówczesnego zastępcy naczelnego dowódcy do spraw polityczno-wychowawczych, otrzymałem mundur oficera bez stopnia i zaświadczenie, podpisane przez generała, stwierdzające, że „ob. Osmańczyk Edmund udaje się do armii czynnej jako specjalny korespondent «Rzeczypospolitej». Władzom wojskowym rozkazuję udzielić mu wszelkiej pomocy przy wykonywaniu zadania. Posiada broń boczną nr...".

Numer broni nie był wpisany, bo jej nie dostałem.

- Wszystka broń jest na froncie, tam sobie znajdziecie jakieś piękne parabellum i wpiszecie numer - usłyszałem na pożegnanie od zastępcy naczelnego dowódcy.

Zachował mi się ten mały arkusik papieru z okrągłymi pieczęciami z piastowskimi orłami, czerwoną: „,Wojsko Polskie. Naczelne Dowództwo”, i fioletową: „Zastępca dowódcy I Armii WP do spraw pol.-wych.”.

Pod tą drugą pieczęcią jest późniejszy dopisek ręką pułkownika Piotra Jaroszewicza, wówczas zastępcy generała Stanisława Popławskiego, dowódcy I Armii: "Zezwalam na pobyt w jednostkach I Armii”. A na odwrocie tą samą ręką: „Ułatwić przejazd na front razem z naszymi korespondentami. P.J. 27 IV 45".

Zanim jednak uzyskałem te dwa bardzo ważne dopiski, w mundurze ruszyłem z Włoch do Łodzi, a z Łodzi do Gdańska (E.J. Osmańczyk, Był rok 1945..., Warszawa 1970, s. 134-135).

\section{1 kwietnia 1945, środa}

1. Podczas czwartego plenarnego posiedzenia Miejskiej Rady Narodowej w Łodzi zostaje podjęta decyzja o reorganizacji Wydziału Oświaty i Kultury. Od tej chwili funkcjonować będą osobno Wydział Oświaty oraz Wydział Kultury i Sztuki (Politechnika warszawska w Łodzi. Umowa z rektorem politechniki, GL 1945, nr 90 [130], s. 4).

2. W prasie:

2.1. artykuł Bolesława Dudzińskiego na temat roli pisarza w „nowej Polsce":

Nowa rzeczywistość polska, zrodzona z krwawego chaosu wojny i okupacji, stawia polskiego pisarza w obliczu nowych i odpowiedzialnych obowiązków. [...] Literatura, przestając być uzupełnieniem jadłospisu snobów czy pożywką dla wybranych, ma się stać dobrem powszechnie dostępnym i społecznie użytecznym, zestrojonym harmonijnie z całokształtem 
narodowego wysiłku. [...] [U]zyskując możność spokojnej i nieskrępowanej pracy twórczej, biorą jednocześnie pisarze polscy na swe barki ogrom doniosłych obowiązków natury społecznej i obywatelskiej, którym podołać nie zawsze może będzie rzeczą łatwą. W związku z tym zachodzi nieodzowna konieczność wyjścia z zaczarowanych kręgów egocentryzmu i izolacjonizmu, konieczność aktualizacji i aktywizacji wysiłku twórczego, zespolenia go z myślą i czynem szerokich mas ludowych, jako głównych odbiorców nowej produkcji literackiej (B. Dudziński, Stanowisko pisarza w nowej Polsce, R 1945, nr 87 [117], s. 3).

\section{2 kwietnia 1945, czwartek}

1. Odczyt Reginy Kobryńskiej pt. Front Narodowy w Polsce w Centralnym Robotniczym Domu Kultury, ul. Piotrkowska 243 (Odczyty w Rob. Domu Kultury, GL 1945, nr 83 [123], s. 4).

2. Odczyt docent Zofii Lissy pt. O muzyce sowieckiej w Studiu Teatralnym, ul. Gdańska 32 (Odczyt o muzyce sowieckiej, GL 1945, nr 88 [128], s. 4).

3. W "Robotniku”:

3.1. wypowiedź na temat programu oświatowego, stwarzającego szansę na włączenie niższych warstw społecznych w obieg kultury; szczególną uwage poświęcił autor - istotnej z punktu widzenia propagandy - problematyce odbioru prasy:

Pierwszą ogólnokrajową potrzebą jest likwidacja analfabetyzmu, włączenie w orbitę oddziaływania gazety czy książki tych wszystkich, którzy byli od niej odcięci. Potrafiących czytać i pisać przejmą szkoły powszechne dla dorosłych, by ich z kolei przekazać uniwersytetom powszechnym i ludowym. Tam, gzie nauka nie może być zorganizowana w stałych zespołach, pracujących równomiernie, należałoby organizować dorywcze kursy [...].

Sprawą niewątpliwie zasadniczej wagi jest umiejętność czytania gazety. Z opowiadań nauczycieli i działaczy oświatowych wynika, że duża część czytelników gazet nie umie czy nie ma wprawy w rozumieniu często najprostszego artykułu gazetowego. Nie zna ponadto sensu w układzie artykułów, poprzez który pismo stara się być pewną zamkniętą w sobie całością. Należałoby po dzielnicach partyjnych, w związkach zawodowych i innych organizacjach społecznych w mieście i na wsi organizować zespoły dobrego czytania gazet. Kierownictwo tych instytucji powinno zresztą nawiązać kontakt z redakcjami pism i zażądać od nich wysłania swych współpracowników, którzy by nauczyli rozumienia gazety (P., Oświata dorostych, R 1945, nr 88 [118], s. 4). 


\section{przed 13 kwietnia 1945}

\section{1. Łódzka „konferencja organizacyjna” Poalej-Sjon-Lewicy:}

Po uczczeniu pamięci poległych w czasie walk w getcie oraz w czasie powstania w Warszawie bojowców i działaczy ruchu, wygłosił referat programowy przewodniczący podziemnego Centralnego Komitetu partii poseł do KRN dr Adolf Berman. [...]

Konferencje „Poalej-Sjonu” - lewicy, po ożywionej dyskusji, jednomyślnie zaakceptowały linię polityczną podziemnego ruchu i stanęły bez zastrzeżeń na gruncie Krajowej Rady Narodowej i Rządu Tymczasowego (Konferencja Poalej-Sjon-Lewicy, GL 1945, nr 91 [131], s. 4).

\section{3 kwietnia 1945, piątek}

1. Inspirowane przez komunistów wiece robotników łódzkich, „żądających" podpisania przez Polskę traktatu o przyjaźni ze Związkiem Sowieckim:

W fabryce Johna w Łodzi odbył się masowy więc robotniczy w związku z porozumieniem zawartym między Związkiem Radzieckim a Jugosławią.

Przewodniczący Rady Zakładowej ob. Ruta i ob. Rachowski wygłosili referaty na temat zawartego układu, po czym obecni uchwalili jednogłośnie rezolucję, domagającą się od Rządu Tymczasowego R.P. poczynienia kroków celem zawarcia przez Polskę analogicznego układu ze Związkiem Radzieckim. [...]

Równocześnie odbyło się olbrzymie zgromadzenie w fabryce włókienniczej b. f-my Scheibler i Grohman. I tu wielkie rzesze robotników po wysłuchaniu referatu ob. Jóźwiaka uchwaliły rezolucję domagającą się zawarcia przez Polskę ze Związkiem Radzieckim paktu analogicznej treści jak pakt radziecko-jugosłowiański. [...]

Z okazji zawarcia umowy o przyjaźni pomiędzy Związkiem Radzieckim a Jugosławią odbył się w piątek 13 bm. w Łodzi, w fabryce I.K. Poznańskiego masowy więc robotników fabryki. Referat polityczny na temat zawartej umowy wygłosiła ob. Matczakowa, pracownica fabryki.

Zebrani uchwalili następnie rezolucję następującej treści: [...]

„Z wielką radością przyjęliśmy wiadomość o zawarciu między Związkiem Radzieckim a Jugosławią umowy o przyjaźni, pomocy wzajemnej i współpracy powojennej. Jest to doniosłej wagi wkład w wielkie dzieło przyjaźni narodów słowiańskich, w świętą sprawę walki z faszyzmem hitlerowskim, w dzieło powojennej współpracy narodów, miłujących wolność, pokój i demokrację.

My Polacy szczególnie cenimy przyjaźń Związku Radzieckiego, któremu zawdzięczamy wyzwolenie z jarzma hitlerowskiego. Armia Czerwona wraz z naszym Wojskiem Polskim krwią swoją przywróciła 
nam wolną Ojczyznę. Związek Radziecki pomaga nam w odbudowie stolicy naszej, bohaterskiej Warszawy. W tych dniach przybył do Łodzi wielki transport wełny i bawełny ze Związku Radzieckiego dla fabryk włókienniczych.

W przyjaźni ze Związkiem Radzieckim widzimy gwarancję naszej wolności i niepodległości. Związek Radziecki to nasz najlepszy, najwierniejszy i najpotężniejszy sojusznik.

Dlatego my, robotnicy fabryki Poznańskiego, zwracamy się do Was, Obywatelu Prezydencie i Obywatelu Premierze, z prośbą, aby nasz Rząd Tymczasowy poczynił starania w kierunku zawarcia ze Związkiem Radzieckim układu o przyjaźni, pomocy wzajemnej i współpracy powojennej.

Niech żyje wieczysta przyjaźń Polski i Związku Radzieckiego" (Spoteczeństwo polskie żąda zawarcia traktatu o przyjaźni z ZSRR. Wiece w fabrykach Scheiblera, Johna i Poznańskiego w Łodzi. Rezolucje zgromadzeń robotników warszawskich, GL 1945, nr 92 [132], s. 4).

2. Oficjalna inauguracja „Piątków Literackich”, cyklu imprez organizowanych przez łódzki oddział Związku Zawodowego Literatów Polskich:

Jako pierwszy odczyt dyskusyjny wygłosił Mieczysław Jastrun referat O bezdziejowości literatury polskiej. Prelegent wystąpił przeciwko bezdziejowemu, ponadczasowemu pojmowaniu sztuki w ciągu ostatnich 100 lat. Myli się pisarz, który sądzi, że może stać z dala od historycznych wydarzeń. Każdy twórca związany jest z nurtem dziejów swego narodu, już przez to samo, że posługuje się w swojej pracy tworzywem narodu - słowem. Rozprawiając się z przesądami o wyższości utworu abstrakcyjnego nad utworem społecznym, zauważył prelegent, że literatura ostatnich 20-tu lat była ucieczką w „Sanatoria pod klepsydrą", stanowiące antytezę rzeczywistości historycznej, której pisarze obawiali się panicznie. Tworząca się obecnie nowa rzeczywistość historyczna na ziemiach polskich wpływa zdecydowanie na inne ukształtowanie się zagadnień literackich. Kultura ludowa może rozwijać się dopiero teraz, gdy pałace i dwory zostały zamienione na Domy Kultury i Biblioteki. (Piątki Literackie, R 1945, nr 92 [122], s. 4).

\section{W prasie:}

3.1. artykuł Janiny Kulczyckiej-Saloni zawierający charakterystykę sytuacji szkolnictwa i postulaty zmian systemowych w oświacie:

Truizmem byłoby powtarzanie starej prawdy, że szkoła stanowi jedną z podstawowych funkcyj życia społecznego, że tam, gdzie istnieje świadoma swej odrębności grupa społeczna, tam musi istnieć problem wychowania jako zasadniczy warunek przetrwania tej grupy dłużej niż życie jednego pokolenia jej członków. Nic też dziwnego, że w momentach 
decydujących, w momentach ścierania się światopoglądów, toczyć się musi walka o szkołę jako narzędzie i teren kształtowania przyszłości. Bo oczywiste jest, że młode pokolenie pójdzie za tym, kto je będzie wychowywał, za tym, z kim się zetknie w pierwszej formie społecznego życia w szkole. [...]

I dlatego teraz, kiedy przeżywamy tak doniosłe zmiany w gospodarczej, społecznej i kulturalnej strukturze naszego państwa, szkoła nie może pozostać poza obrębem tych zmian, inaczej stanie się szkodliwym anachronizmem.

Są pewne dziedziny tego bogatego zjawiska, zwanego „szkołą”, które odziedziczyliśmy po Polsce przedwrześniowej i które, jako jej smutne dziedzictwo, wlec będziemy za sobą niewątpliwie przez czas jakiś: tą dziedziną jest ustrój szkolnictwa, jego ramy organizacyjne. [...] Mimo to w stare ramy, póki one istnieją, wlać należy nową treść. Szkoła wadliwa pod względem organizacyjnym może pod wieloma względami odpowiadać wymaganiom współczesności. Można tego dokonać przez doraźną zmianę obowiązujących dotychczas dawnych programów.

Jeśli nawet postawimy naczelny postulat programu, że przedmiotem zainteresowania ma być „Polska i jej kultura”, to, pomijając niewłaściwe zacieśnienie horyzontu młodzieży do spraw polskich, możemy tu wprowadzić daleko idące zmiany. Bo jakże inna jest ta Polska, o której mówić dzieciom będziemy: Polska, która się staje, która realizuje się z dnia na dzień, zmieniona przede wszystkim geograficznie, przesunięta ku zachodowi, wzbogacona o prastare ziemie śląskie i pomorskie, zjednoczona sojuszem z bratnimi narodami słowiańskimi, rozumiejąca kapitalną konieczność oparcia się germańskiemu Drang nach Osten. Polska dzisiejsza, która wreszcie przez dokonanie reformy rolnej odrabia swe wiekowe opóźnienie, przekształca swą spóźnioną, wsteczną strukturę społeczną.

I o tej Polsce, która się staje i która w znacznej mierze od nas zależy, uczyć ma nauczyciel dzieci i młodzież na wszelkich poziomach i ma ich wychowywać na godnych tej Polski obywateli [...], wszczepiając w młodzież lojalność wobec własnego państwa i istotne jego ukochanie (J. Kulczycka-Saloni, Oblicze wychowawcze szkoty, GL 1945, nr 91 [131], s. 3),

3.2. felieton-protest przeciwko zatrudnieniu Jerzego Waldorffa - określanego jako „wiadomy pan”, który „abecadło faszyzmu [...] opanował [...] znakomicie" - w łódzkim Wojewódzkim Wydziale Kultury i Sztuki (Zez. [R. Werfel], Prosto z mostu o ABC, GL 1945, nr 91 [131], s. 4),

3.3. propagandowo-satyryczny utwór wierszowany Stanisława Sojeckiego pt. Malkontent (RZ 1945, nr 97 [137], s. 4).

\section{przed 14 kwietnia 1945}

1. Zakończenie wstępnego etapu organizacji łódzkiego Teatru Miejskiego (pod dyrekcją Henryka Szletyńskiego): 
Cele Rady Artystycznej Teatru są bardzo ambitne. Poszukiwanie współczesnego repertuaru oraz znalezienie współczesnej formy dla repertuaru klasycznego - oto wytyczne [...].

W tej chwili kierownictwo teatru zapoznaje się ze współczesnym repertuarem radzieckim. W tym celu wyjechał do Moskwy reżyser Teatru - [Stefan] Lencz.

Poza tym skompletowany już został zespół artystyczny Teatru Miejskiego i prace wstępne do rozpoczęcia działalności scenicznej są w pełnym toku (Otwarcie studia teatralnego w Łodzi, GL 1945, nr 97 [137], s. 4).

Teatr pracować będzie pod kierownictwem Rady Artystycznej w składzie: H. Szletyński (kier. artystyczny i reżyser naczelny), red. K. Korcelli (kier. literacki), dr J. Kreczmar (kier. repertuarowy), prof. Wł. Daszewski (naczelny dekorator), T. Sygietyński (kierownik muzyczny), J. Kochanowicz (kier. Studio), J. Chojnacka (kier. pracy), K. Wilanowski (reżyser).

Wśród zaangażowanych dotychczas artystów figurują m.in. nazwiska N. Andrycz, E. Bonacka, St. Jarkowska, J. Kossocka, Z. Tymowska, M. Miedzińska, T. Białoszyński, M. Borowy, K. Pawłowski. Ponadto zaangażowany został młody, ciekawie zapowiadający się reżyser Stefan Lencz.

W dziale dekoracji pracować będzie: Jędrzejewski, Przeradzka.

Na inaugurację sezonu dyrekcja przygotowuje Beaumachais'go Cyrulik sewilski i Wesele Figara w jednym rzucie widowiskowym pt. Sto szaleństw. Tło: przedwiośnie wielkiej rewolucji francuskiej. [...]

Kierownictwo teatru zdaje sobie sprawę, iż placówka teatralna związana być musi z potrzebami mas i tymi potrzebami pragnie kierować się w swojej pracy (K. Korcelli, Teatr Miejski w Łodzi, GL 1945, nr 100 [140], s. 4).

\section{4 kwietnia 1945 , sobota}

\section{Premiera Dożywocia Fredry w Teatrze Wojska Polskiego:}

W dniu dzisiejszym Teatr Wojska Polskiego daje po raz pierwszy Dożywocie Aleksandra Fredry. Reżyseruje Jan Kreczmar, oprawę dekoracyjną przygotował Stanisław Teisseyre. W popisowej roli Łatki ukaże się Jacek Woszczerowicz. Obsadę innych ról stanowią: Gosławska (Rózia), Bogucki (Birbancki), Bryliński (Orgon), Butrym (Michał Lagena), Grabowski (Rafał Lagena), Grolicki (Twardosz), Maliszewski (Doktór Hugo) i Wołłejko (Filip).

W niedzielę o g. $11 \mathrm{~min} .30 \mathrm{w}$ południe Wesele, po południu Dożywocie, które od wtorku grane będzie codziennie. Początek przedstawień Dożywocia o godzinie 16 minut 15 punktualnie („Dożywocie” w Teatrze Wojska Polskiego, RZ 1945, nr 98 [238], s. 4).

2. Oficjalna inauguracja działalności studium aktorskiego przy Teatrze Miejskim w Łodzi: 
Dnia 14 bm., w sobotę odbyło się w b. pałacu Poznańskich otwarcie studia teatralnego. Studio to zostało zorganizowane przez kierownictwo Teatru Miejskiego w Łodzi, celem kształcenia przyszłego pokolenia aktorów.

Dyrektor Szletyński w przemówieniu wygłoszonym na uroczystym otwarciu studia do zgromadzonych przedstawicieli społeczeństwa, sztuki i uczniów studia powiedział m.in.:

Rozpoczynamy naszą działalność [...] od akcji wychowawczej młodego pokolenia aktorskiego. [...] Zamiast wystawiać sztuki nieodpowiednie i grać je źle, byle prędko, na kolanie, wolimy nieco dłużej się przygotować. [...]

Następnie dyr. Szletyński charakteryzuje materiał ludzki, który się zgłosił na studio: „Wszyscy adepci pochodzą ze sfer robotniczych, większa ich część była na robotach w Niemczech, niektórzy siedzieli lata w więzieniach i obozach. Znaczna część ma jeszcze pewien «nalot» niemiecki w mowie. Oczywiście, usuniemy to, jak i szereg innych braków. Uprzedziliśmy ich, że sztuka - to praca, bardzo ciężka praca, a nie łatwe i tanie oklaski i wawrzyny".

Stworzenie w obecnych ciężkich warunkach studia teatralnego kosztowało niemało wysiłku, a stało się możliwe przy wielkiej pomocy, którą okazała Rada Miejska i Polska Partia Robotnicza.

Przemawiali nadto przedstawiciele władz państwowych i miejskich [...]. Znany poeta robotniczy, St.R. Dobrowolski, podkreślił sens i znaczenie hasła demokratyzacji sztuki:

Byliśmy narodem 20-milionowym, a niektórzy nawet twierdzili, że 34-milionowym, w którym zaledwie 100 czy 200 tysięcy ludzi korzystało z dobrodziejstw kultury, obecnie chcemy, aby 20 milionów chłopów i robotników - cały naród polski - stał się narodem kulturalnym, aby sztuka przestała być luksusem i przywilejem garstki nierobów - na tym polega demokratyzacja sztuki i kultury. Jeżeli pomożecie nam w tym, jeżeli pójdziecie po tej linii - dobrze, jeżeli nie, to oświadczam, że przepędzimy was z tego pałacu na „cztery wiatry”...

Artystka Teatru Miejskiego, Jadwiga Chojnacka, podniosła następnie znamienny fakt, że jeżeli 3 miesiące temu nie mogliśmy jeszcze marzyć o pracy nad odbudową sztuki polskiej, a obecnie obradujemy w tym pałacu, to stało się to za sprawą sprzymierzonej Armii Czerwonej i walczącego ramię przy ramieniu z nią - Wojska Polskiego. O tym musimy pamiętać stale i przy każdej okazji podnosić.

W końcu przedstawiciel uczniów Studia, bardzo wzruszony, obiecywał uroczyście w imieniu swych kolegów i koleżanek, że dołożą wszelkich starań, by sumienną i gorliwą pracą zasłużyć na zaszczytny tytuł artystów ludowych, służących nie garstce uprzywilejowanych, lecz całemu narodowi (Otwarcie studia teatralnego w Łodzi, GL 1945, nr 97 [137], s. 4).

\section{Uruchomienie świetlicy robotniczej przy fabryce „Franciszek Ramisz”:}

Dzień 14-ty kwietnia był dla robotników fabryki „Franciszek Ramisz” wielkim świętem. Dnia tego odbyło się bowiem uroczyste otwarcie 
świetlicy. Odśpiewaniem Roty zaczęła się część oficjalna. Zebranie zagaił przewodniczący Rady Załogowej ob. Grzegorczyk. Zgromadzonych przywitał w gorących słowach obecny kierownik fabryki Urbańczyk Stanisław oraz delegat do Związku Zawodowego - człowiek rady załogowej, tow. Guzicki.

Obecni na uroczystości przedstawiciele partyj robotniczych, prasy, rady związków zawodowych, miejskiego urzędu propagandy, podkreślali w swych przemówieniach nowy charakter robotnika polskiego w dzisiejszych zakładach pracy. Fabryka jest dziś dla robotnika nie tylko miejscem zarobkowania, lecz także nieodłączną częścią jego życia. Robotnik fabryki jest jej współgospodarzem.

Świetlica fabryczna umożliwia mu po pracy godziwą rozrywkę, wymianę myśli z towarzyszami, pozwala na pogłębienie wiedzy.

"Świetlica robotnicza jest świątynią ducha mas" - wyraził się pięknie tow. Śmigielski. - „W niej wykuwa się i krystalizuje myśl i siła duchowa robotnika. Musimy dbać o czystość głoszonych zasad, o zdrowy i prawdziwie demokratyczny ich sens".

Zrozumienie poważnego zadania fabryki w dobie odbudowy kraju cechowało każdą wypowiedź.

Wznoszono okrzyki na cześć Rządu Tymczasowego, przyjaźni polsko-radzieckiej, Armii Czerwonej i Wojska Polskiego.

Orkiestra kilkakrotnie odegrała hymn państwowy i hymn Związku Radzieckiego.

Wydany był wspólny obiad. Ponowiły się toasty. Wśród robotników znaleźli się ochotnicy do odśpiewania i zadeklamowania własnych utworów. Nastrój od początku serdeczny, stawał się coraz bardziej miły i bliski. Uroczystości zakończyły ludowe tańce i pieśni (D.E., Otwarcie robotniczej świetlicy, R 1945, nr 91 [121], s. 4).

4. Kolejne wiece łódzkich robotników w związku z planowanym przez komunistów zawarciem układu o przyjaźni ze Związkiem Sowieckim.

W dniu 14 bm. odbyły się w 10-ciu fabrykach łódzkich dalsze masowe wiece robotników i inteligencji pracującej, na których zebrani w licznych rezolucjach, skierowanych do Prezydenta Krajowej Rady Narodowej ob. Bieruta i Premiera Rządu Tymczasowego R.P. ob. Osóbki-Morawskiego, domagali się zawarcia przez Polskę ze Związkiem Radzieckim analogicznego paktu, jaki zawarł Rząd Radziecki z Jugosławią. [...]

Wiece odbyły się w następujących wielkich fabrykach włókienniczych: Biederman, Buhle, Kinderman, Łódzka Fabryka Nici, w zakładach metalurgicznych Mueller i Seidel, Weigt, oraz w instytucjach użyteczności publicznej, Gazowni, Elektrowni i Tramwajach Miejskich przy udziale wielu tysięcy osób (Społeczeństwo polskie domaga się zawarcia układu o przyjaźni z ZSRR. Dalsze wiece w Warszawie i w Łodzi, GL 1945, nr 93 [133], s. 1). 
5. W „Głosie Ludu” (1945, nr 92) blok wypowiedzi poświęconych postaci Włodzimierza Majakowskiego - między innymi wiersz P. Hertza Majakowskij, artykuł Leona Gomolickiego Wtadimir Majakowskij oraz niepodpisany tekst pt. 14-IV-1930 - uzupełnionych Kronika kulturalna ZSRR:

Włodzimierz Majakowski był i pozostanie bliski proletariatowi polskiemu, polskiej klasie robotniczej. Gdy walczyliśmy jeszcze z reakcją w Polsce przedwrześniowej, gdy wbrew nagonce antyradzieckiej sanacji czy endecji mówiliśmy narodowi polskiemu prawdę o Związku Radzieckim, gdy mimo sanacyjnych Berez i Brześciów walczyliśmy przeciw zgubnej polityce zagranicznej naszej reakcji, walczyliśmy o sojusz Polski i ZSRR jego poezja była dla nas, konsekwentnych marksistów polskich, nie tylko źródłem pokrzepienia i otuchy, ale także potężną bronią propagandową, bronią agitacyjną. [...] Dziś słowo Majakowskiego mówi całemu narodowi polskiemu o tych, którym Polska zawdzięcza swą wolność - o narodach ZSRR (14-IV-1930, GL 1945, nr 92 [132], s. 3).

Twórcze życie Majakowskiego - to bliski obecnie dla nas temat. To temat formowania się pisarza w bojowej społecznej rzeczywistości, kiedy potrzeby wojny i potrzeby rekonstrukcji zniszczonego kraju wymagają od pisarza żywej reakcji, czynnego udziału i kierownictwa. Z drugiej strony doświadczenie Majakowskiego uczy nas, że ten udział nieformalny i niefikcyjny, lecz twórczy i rzeczywisty - może być osiągnięty tylko wtedy, kiedy pisarz jest organicznie wciągnięty do walki, kiedy świadomość jego jest skrystalizowana, a celowość łączy się z funkcją. Od krystalizacji świadomości zależy wypracowanie prostego i bijącego w cel języka, dokładnego stylu, bo tylko taki język i taki styl pisarza może być przyjęty i zrozumiany przez szerokie masy (L. Gomolicki, Władimir Majakowskij, GL 1945, nr 92 [132], s. 3).

\section{5 kwietnia 1945, niedziela}

\section{Poranek literacki w Robotniczym Domu Kultury:}

W dniu 15 kwietnia odbędzie się o godz. 11-ej poranek autorski w Robotniczym Domu Kultury. Program literacki poprzedzi odczyt Adama Galińskiego [właśc. Ludwika Stolarzewicza] pt. Tradycje literackie Łodzi. W poranku biorą udział m.in. Czarski Tadeusz, Czerwińska Zofia, Garda Czesław, Ptakowski Marek, Pawlak Władysław, Ubysz Jerzy i Żak Lucjan. Całkowity dochód z imprezy przeznaczony jest na Fundusz Odbudowy Warszawy (Poranek autorski w Robotniczym Domu Kultury, RZ 1945, nr 97 [237], s. 4). 
2. Zebranie członków i kandydatów na członków łódzkiego oddziału Związku Zawodowego Polskich Artystów Plastyków; lokal Wydziału Kultury i Sztuki, al. Kościuszki 70 (Walne zebranie, RZ 1945, nr 97 [237], s. 4).

3. Walne zgromadzenie członków łódzkiego oddziału Związku Zawodowego Muzyków; lokal Rady Okręgowej Związków Zawodowych, ul. Strzelecka 2 (Uwaga muzycy!, RZ 1945, nr 97 [237], s. 4).

4. W redakcji "Głosu Ludu" zebranie „korespondentów robotniczych" tego dziennika:

Zebranie zagaił redaktor Werfel referatem o sytuacji politycznej.

Sekretarz redakcji - tow. Uzdański omówił zadania korespondentów robotniczych: „Gazeta dla spełnienia swojego zadania musi pracować w jak najściślejszym kontakcie z masami pracującymi [...]. Reakcja działa i dezorganizuje naszą pracę. Tylko korespondent robotniczy może pomóc gazecie w unieszkodliwieniu sabotażystów, wskazując konkretne fakty ich działalności".

Tow. Bychowska - kierowniczka działu korespondencji - zwróciła się do zgromadzonych z prośbą o ściślejszy kontakt.

$\mathrm{Z}$ kolei poruszali sprawę prasy uczestnicy konferencji. Przedstawiciel fabryki Jan Künze obecnie „Higiena” tow. Janas omówił sprawę kolportażu. Robotnik idzie do pracy o 7-ej, kiedy gazety jeszcze nie ma, a wraca o 4-ej, kiedy już wysprzedana. Sprawa kolportażu musi być tak rozwiązana, by gazeta regularnie docierała do pracujących. Delegat Monopolu Tytoniowego opowiedział, jak zorganizował u siebie sprawy kolportażu. Zaproponował on robotnikom zaprenumerowanie gazet. W rezultacie robotnicy otrzymują regularnie prasę. [...]

Tow. Pokorski zaproponował umieszczenie na fabrykach skrzynek „Głosu Ludu”. W każdej fabryce powinna być skrzynka, do której robotnik będzie mógł złożyć korespondencję z życia fabryki. Tow. z Bałut skarżył się, że gazeta do jego dzielnicy rzadko dochodzi. A chodzi przecież o to, by "Głos Ludu” kupował nie spekulant, a właśnie robotnik. [...]

Zebranie zakończył tow. Werfel, odpowiadając na poszczególne pytania. Stwierdził, że sprawa kolportażu musi być rozwiązana. Gazeta, żeby spełniała swoje zadania, winna docierać do wszystkich pracujących. Każda korespondencja, która wpływa do "Głosu Ludu”, jest czytana i wykorzystywana. Staramy się w miarę możliwości poruszać bolączki robotnicze i często osiągamy skutek. [...] Redakcja postara się umieścić skrzynki „Głosu Ludu” w każdej fabryce i usprawnić kolportaż, wprowadzić dział informacji dla Rad Zakładowych. Zakończył apelem o współpracę z pismem (Konferencja korespondentów robotniczych "Głosu Ludu", GL 1945, nr 96 [136], s. 4).

5. Otwarcie Centralnej Szkoły Partyjnej koncesjonowanej Polskiej Partii Socjalistycznej: 
W programie Szkoły, między innymi tematy takie jak: Zagadnienia gospodarcze; Sprawa Rolna; Współpraca międzypartyjna; Problemy ziem zachodnich; Bieżące zagadnienia polityczne. Przewidziany jest udział słuchaczy miejscowych i zamiejscowych, którzy będą skoszarowani przy Dzielnicach Polskiej Partii Socjalistycznej (Z życia partii: Centralna Szkoła Partyjna, R 1945, nr 91 [121], s. 4).

\section{W prasie:}

6.1. list otwarty kandydatów na studia w Uniwersytecie Łódzkim:

Otrzymaliśmy zbiorowy list od studentów, w którym grono studentów z Katowic pisze:

„W ostatnich dniach lutego zostały ogłoszone zapisy na Państwowy Uniwersytet Łódzki w terminie do 15 marca r.b.

Miało być otwartych 17 wydziałów, w tym medyczny, stomatologiczny, Politechnika, prawny i wiele innych. Młodzież studiująca, widząc nareszcie możność swobodnego studiowania bez rozpolitykowanych młodzieńców spod znaku ONR, tłumnie przybyła do Łodzi, nie bacząc na trudne warunki podróży i wysokie koszty utrzymania. [...] Niestety w dniu 13.3 przybyli do Łodzi ze zdumieniem dowiedzieli się, że z początkowo projektowanych 17 wydziałów mają być tylko cztery i to stosunkowo mało uczęszczane, tzn. humanistyczny, społeczny, pedagogiczny i matematyczno-przyrodniczy. [...] [K]westia otwarcia wyższych uczelni w Łodzi została załatwiona niepoważnie. [...] Rozgoryczenie wśród tej młodzieży jest zupełnie zrozumiałe [...]" (Listy naszych Czytelników: Młodzież o uniwersytecie, RZ 1945, nr 99 [239], s. 3).

\section{5-20 kwietnia 1945}

1. Kurs „informacyjno-instrukcyjny” dla działaczy Wojewódzkich Komitetów Robotniczych koncesjonowanej PPS:

Jako wykładowcy na kursie przewidziani są tow. OSÓBKA MORAWSKI, SZWALBE, ŚWIĄTKOWSKI, MATUSZEWSKI, AJNENKIEL i inni.

Kurs rozpocznie się w Łodzi [...] w lokalu W.K.R.P.P.S. ul. Cegielniana 189 (nowy nr 45). Wszystkie wojewódzkie Komitety Robotnicze PPS zobowiązane są delegować co najmniej trzech działaczy WKR, w tym sekretarza lub jego zastępcę.

Noclegi i wyżywienie bezpłatne dla wszystkich uczestników kursu zapewnione. Zgłoszenia kierować do CKW PPS Warszawa, ul. Śnieżna 4 i bezpośrednio do WKR Łódź, ul. Cegielniana 189 (R 1945, nr 87 [117], s. 3). 


\section{B I B L I O GRA F I A}

\section{OPRACOWANIA}

Dakowicz P., "Lecz ty spomnisz, wnuku”. Recepcja Norwida w latach 1939-1956. Rzecz o ludziach, ksiażkach i historii, Warszawa 2011.

\section{KORESPONDENCJA, WSPOMNIENIA}

Huszcza J., Zdarzenia i zwierzenia, Łódź 1965.

Osmańczyk E.J., Był rok 1945..., Warszawa 1970.

Zaremba Z., Wojna i konspiracja, Kraków 1991.

TEKSTY Z PRASY ŁÓDZKIEJ (1945)

\section{Artykuły propagandowo-ideologiczne}

Kulczycka-Saloni J., Oblicze wychowawcze szkoty, GL 1945, nr 91 (131), s. 3 [o nowej oświacie].

Łódzka organizacja PPS przy pracy, R 1945, nr 80 (110), s. 4.

Raabe H., Nieco o szkolnictwie wyższym, GL 1945, nr 86 (126), s. 7.

Społeczeństwo polskie domaga się zawarcia układu o przyjaźni z ZSRR. Dalsze wiece w Warszawie i w Łodzi, GL 1945, nr 93 (133), s. 1.

Społeczeństwo polskie żąda zawarcia traktatu o przyjaźni z ZSRR. Wiece w fabrykach Scheiblera, Johna i Poznańskiego w Łodzi. Rezolucje zgromadzeń robotników warszawskich, GL 1945, nr 92 (132), s. 4.

Werfel R., Uczelnie wyższe - sprawa Narodu, GL 1945, nr 86 (126), s. 7.

\section{Felietony}

Dobrowolski S.R., Uspołecznić prace pisarska!!, R 1945, nr 80 (110), s. 3.

Gomolicki L., Westerplatte broni się..., R 1945, nr 86 (116), s. 3.

Gomolicki L., Dobrowolski S.R., Krew na butach, R 1945, nr 84 (114), s. 4.

Waldorff J., Kto późno do Łodzi..., R 1945, nr 83 (113), s. 4.

Wyszomirski J., Jedna zima w Gdyni, RZ 1945, nr 92 (232), s. 4-5.

Zez. [Werfel R.], Prosto z mostu o ABC, GL 1945, nr 91 (131), s. 4.

\section{Informacje i relacje prasowe}

D.E., Otwarcie robotniczej świetlicy, R 1945, nr 91 (121), s. 4.

E.D., Uniwersytet Państwowy w Łodzi, GL 1945, nr 86 (126), s. 8.

Irena Dubiska w Łodzi, RZ 1945, nr 87 (227), s. 4.

Juliusz Osterwa w Łodzi, PZ 1945, nr 60, s. 4.

Konferencja korespondentów robotniczych "Głosu Ludu”, GL 1945, nr 96 (136), s. 4.

Konferencja Poalej-Sjon-Lewicy, GL 1945, nr 91 (131), s. 4.

Konferencja woj. sekretarzy Komitetów powiatowych i miejskich PPR w Łodzi, GL 1945, nr 90 (130), s. 3. 
Korcelli K., Teatr Miejski w Łodzi, GL 1945, nr 100 (140), s. 4.

Kronika kulturalna, GL 1945, nr 86 (126), s. 3.

Nowe władze $€ K S-u$, GL 1945, nr 86 (126), s. 8.

Otwarcie Centralnej Szkoty Partyjnej PPR, GL 1945, nr 88 (128), s. 3.

Otwarcie studia teatralnego w Łodzi, GL 1945, nr 97 (137), s. 4.

Otwarcie Szkoty Oficerskiej w Łodzi, RZ 1945, nr 93 (233), s. 4.

Otwarcie świetlicy w zakładach Geyera, RZ 1945, nr 92 (232), s. 6.

Politechnika warszawska w Łodzi. Umowa z rektorem politechniki, GL 1945, nr 90 (130), s. 4.

PPS uczciła przyłączenie Gdańska, R 1945, nr 86 (116), s. 4.

Udział młodzieży szkolnej w pracach organizacji społeczno-oświatowych, R 1945, nr 81 (11), s. 4.

Utani witają morze. Uroczysty akt zaślubin Polski z Battykiem, GL 1945, nr 81 (121), s. 2.

Wznowienie prac Przysp. Wojskowego, R 1945, nr 82 (112), s. 4.

Z okazji odzyskania Gdańska i Gdyni odbyła się w Łodzi wielka manifestacja na Placu Wolności, GL 1945, nr 83 (123), s. 4.

Z życia partii: Centralna Szkoła Partyjna, R 1945, nr 91 (121), s. 4.

Zagościński J. [Huszcza J.], Pierwsza rotacja warszawska, RZ 1945, nr 94 (234), s. 4.

\section{Listy do redakcji gazet}

Listy naszych Czytelników: Młodzież o uniwersytecie, RZ 1945, nr 99 (239), s. 3.

\section{Ogłoszenia, zapowiedzi, wezwania, zachęty}

Komunikacja lotnicza, GL 1945, nr 85 (125), s. 4.

Kurs „Wici”, R 1945, nr 87 (117), s. 4.

Nabożeństwo za artystów, GL 1945, nr 84 (124), s. 4.

Odczyty w Rob. Domu Kultury, GL 1945, nr 83 (123), s. 4.

Poranek autorski w Robotniczym Domu Kultury, RZ 1945, nr 97 (237), s. 4.

Uwaga muzycy!, RZ 1945, nr 97 (237), s. 4 [dot. zebrania członków Zw. Zaw. Muzyków].

Walne zebranie, RZ 1945, nr 97 (237), s. 4 [dot. zebrania Zw. Zaw. Pol. Artystów Plastyków].

Zebranie Artystów Cyrkowych, R 1945, nr 80 (110), s. 4.

\section{Program „nowej kultury"}

Dudziński B., Stanowisko pisarza w nowej Polsce, R 1945, nr 87 (117), s. 3.

G.I., Teoria i praktyka ob. Przybosia, R 1945, nr 86 (116), s. 3 [dot. „niezrozumialstwa" poezji].

Gomolicki L., Wtadimir Majakowskij, GL 1945, nr 92 (132), s. 3.

Piątki Literackie, R 1945, nr 92 (122), s. 4 [streszczenie odczytu M. Jastruna o „bezdziejowości” polskiej literatury].

Pollak S., Trzy numery „Odrodzenia”, GL 1945, nr 82 (122), s. 3.

\section{Recenzje}

„Dożywocie" Fredry w Teatrze Wojska Polskiego w Łodzi, GL 1945, nr 102 (142), s. 3. 


\section{Rozmowy}

Sokolicz-Wroczyński J., Teatr dla wszystkich w dzisiejszej Polsce. (Rozmowa z Aleksandrem Zelwerowiczem), RZ 1945, nr 94 (234), s. 3.

\section{Utwory literackie na łamach prasy}

Lewin L., Nowe Termopile, RZ 1945, nr 92 (232), s. 4.

Matuszewski R., Idzie wojsko [wiersz], GL 1945, nr 81 (121), s. 3.

Piotrowski J., Umarte ręce [wiersz], R 1945, nr 86 (116), s. 3.

Sojecki S., Malkontent [wiersz], RZ 1945, nr 97 (137), s. 4.

Sojecki S., Spekulanci [wiersz], RZ 1945, nr 87 (227), s. 4.

\section{Zapowiedzi imprez kulturalnych}

Gościnne występy „Wesołej 16-tki”, RZ 1945, nr 91 (131), s. 4.

Od Oki do Wisty, PZ 1945, nr 60, s. 4.

Recital skrzypcowy, RZ 1945, nr 90 (230), s. 4.

\section{Inne teksty prasowe}

14-IV-1930, GL 1945, nr 92 (132), s. 3 [o Majakowskim].

Biblioteczka peperowca, GL 1945, nr 87 (127), s. 3.

Jastrun M., Na drogach wojny, 1945, nr 86, s. 4.

P., Oświata dorostych, R 1945, nr 88 (118), s. 4.

\section{STRESZCZENIE}

Publikacja niniejsza, drugi fragment Kalendarium łódzkiego życia kulturalnego w latach 1945-1946, obejmuje swoim zakresem pierwszą połowę kwietnia 1945 roku, czas organizowania się kultury po przeszło pięciu latach niemieckiego terroru okupacyjnego. W dziejach miasta przełom zimy i wiosny roku 1945 był to okres szczególny - wobec niemal całkowitego zburzenia Warszawy przez Niemców, na terenie Łodzi ulokowały się niektóre spośród komunistycznych urzędów, zaczęli tu także zjeżdżać ważni przedstawiciele życia umysłowego i kulturalnego. Oferowano im mieszkania, pracę $\mathrm{w}$ dynamicznie rozwijającej się, kontrolowanej przez władzę prasie oraz $\mathrm{w}$ tworzonych naprędce instytucjach kultury i uczelniach.

Autor tekstu próbuje - poprzez szczegółową denotację faktów z pogranicza historii, polityki, życia umysłowego i artystycznego - przedstawić mechanizmy i dynamikę najwcześniejszego etapu kulturowo-ideologicznej rewolucji przeprowadzonej w Polsce w latach 1945-1948.

\section{Słowa kluczowe}

Łódź w roku 1945, prasa komunistyczna, łódzkie instytucje kultury, powojenne losy pisarzy, kalendarium, łódzkie życie literackie, propaganda komunistyczna 


\section{Calendar of Cultural Life in Lodz - April 1 $1^{\text {st }}-15^{\text {th }} 1945$}

This publication - an extract from Calendar of Cultural Life in Lodz between 1945 and 1946 (Kalendarium tódzkiego życia kulturalnego w latach 1945-1946) - focuses on the first half of April 1945, when cultural life was reorganised after more than five years of German occupation and terror. In the history of Lodz spring 1945 was a peculiar period - in the face of the virtually complete annihilation of Warsaw, Lodz became the home for some of the Communist offices and was visited by prominent representatives of intellectual and cultural life. They were offered apartments and jobs in the state-controlled press and hastily established cultural institutions and universities.

Through a detailed denotation of facts related to history, politics, and intellectu$\mathrm{al}$ and artistic life, the author of the text makes an attempt to present the mechanisms and the dynamics of the earliest stage of the cultural and ideological revolution implemented in Poland between 1945 and 1948.

\section{Keywords}

Lodz in 1945, Communist press, cultural institutions in Lodz, post-war fates of writers, calendar, literary life in Lodz, Communist propaganda 